\title{
Jenis kelamin anak, pendidikan ibu, dan motivasi dari guru serta hubungannya dengan preferensi makanan sekolah pada anak prasekolah di TK Universitas Muhammadiyah Purwokerto
}

\author{
Atikah Proverawati ${ }^{1}$, Endy P. Prawirohartono², Tjahjono Kuntjoro ${ }^{3}$
}

\begin{abstract}
Background: Preference to foods among children is a predictor of food consumption pattern. Therefore good understanding on food preference of children, factors related to foods most likes and disliked needs to be studied for nutrition education and food supply planning for children.

Objective: To find out the relationship between children sex, education of mother, and motivation of teachers with preference to foods available in school among preschool children at Muhammadiyah University of Purwokerto.

Methods: The study used cross sectional approach by analyzing data of 60 preschool children. Observation and interview were carry out to identify food preference of the children. The independent variables were children sex, education of mothers, and motivation of teachers whereas the dependent variable was preference to foods available in school. Results: Boys liked jellies and quail egg satay whereas girls liked vegetable filled pastry and cracker fries. The result of chi-square test showed that there was difference in food preference between the girls and boys $(p<0.05)$. Education of mothers was also related to preference to foods among children.

Conclusion: There were significant relationship between sex and education of mothers with preference to foods available in school among preschool children.
\end{abstract}

KEY WORDS food preference, preschool, sex of children, education of mothers, motivation of teachers

\section{PENDAHULUAN}

Anak usia prasekolah atau taman kanak-kanak (TK) mempunyai ciri khas karena sedang berada dalam proses tumbuh-kembang. Pada usia ini, mereka peka terhadap pendidikan dan penanaman kebiasaan hidup sehat (1). Aktivitas anak pada usia ini juga tergolong tinggi, sehingga tingginya aktivitas tubuh seiring dengan pertumbuhan tubuh memerlukan pangan dan zat gizi yang tinggi. Makanan ringan merupakan salah satu jenis makanan yang diperlukan anakanak usia prasekolah secara terus-menerus untuk mencukupi semua kebutuhan energi dan zat gizi (2).

Berbagai masalah dalam mengkonsumsi makanan sering terjadi pada anak-anak, seperti: pilih-pilih makan (picky eater), takut akan makanan tertentu (neophobia), mengikuti tren tertentu (faddy), dan kegemukan (obesitas) $(3,4,5,6)$. Selain itu, anak-anak juga seringkali tidak mau mencoba makanan baru dan menolak makanan yang tidak dikenali sebelumnya, meskipun makanan tersebut lebih menyehatkan (4). Pada usia ini, anak-anak cenderung mengklasifikasikan makanan dengan pernyataan suka dan tidak suka (7).

Permasalahan mengenai makanan pada anak-anak ini telah mendapat perhatian dari pemerintah dengan memberikan makanan sekolah di daerah tertinggal dalam program pemberian makanan tambahan anak sekolah (PMTAS). Sekolah atau persatuan orang tua murid dapat pula menyajikan makanan ringan pada waktu istirahat, sehingga anak tidak jajan sembarangan.

Preferensi makanan merupakan suatu prediktor asupan zat gizi dan bisa digunakan sebagai alternatif penilaian kualitas asupan zat gizi (8). Preferensi makanan pada anakanak secara keseluruhan tidak sejalan dengan makanan sehat (9). Preferensi makanan selama usia prasekolah nampak pada makanan yang kaya karbohidrat yang mudah dikunyah. Sereal, roti, dan kraker sering dipilih pada preferensi untuk daging dan makanan tinggi protein lainnya (10). Sebagian anak-anak juga menyukai susu, buah segar, minuman buah dan makanan yang mudah dikunyah seperti keju dan yoghurt, namun sayur-sayuran merupakan kelompok makanan yang kurang disukai oleh anak-anak (11).

Faktor-faktor yang dapat mempengaruhi preferensi makanan pada anak-anak antara lain: jenis kelamin, usia, karakter orang tua dan makanan, motivasi, penyakit, lingkungan, kehidupan sosial orang tua, orang dewasa, dan saudara kandung (12). Interaksi sosial antara anak dengan keluarga dan teman-teman juga dapat mempengaruhi preferensi makanan $(13,14)$. Dalam hal ini, orangtua mempunyai peranan penting dalam pembentukan kebiasaan makan dan preferensi makanan bagi anak-anaknya. Peran langsung orang tua dalam pembentukan pola makan anakanak dapat dilakukan melalui cara bersikap, berperilaku, dan gaya makan (13).

\footnotetext{
Griya Tegalsari Indah, Jl. Kenanga 1 No. 1 Kelurahan Ledug, Kecamatan Kembaran, Kabupaten Banyumas 53182

2 Bagian Anak RSUP Dr. Sardjito, JI. Kesehatan, Yogyakarta, e-mail: eprawirohartono@yahoo.com

3 Bapelkes Gombong, Jl. Wilis No. 1, Gombong, e-mail: kuntjahjono@yahoo.com
} 
Salah satu program kegiatan belajar di TK Universitas Muhammadiyah Purwokerto (UMP) adalah acara makan bersama bagi anak. Selain memberikan tambahan gizi bagi tubuh anak, program ini juga mempunyai kegunaan lain dalam bidang pendidikan. Namun demikian, data dasar mengenai preferensi makanan anak-anak terutama di TK UMP belum ada. Data dasar ini sangat diperlukan sebagai salah satu bahan pelajaran dalam memotivasi anak untuk mengatur asupan makannya.

Penelitian ini bertujuan untuk mengetahui hubungan antara faktor jenis kelamin anak, pendidikan ibu, dan motivasi dari guru dengan preferensi makanan sekolah pada anak prasekolah di TK UMP.

\section{BAHAN DAN METODE}

Penelitian ini dilakukan dengan pendekatan cross sectional design. Populasi penelitian adalah seluruh siswa TK UMP dan sampel meliputi seluruh siswa TK UMP yang memenuhi kiteria inklusi (siswa yang berusia 4-6 tahun dan masuk sekolah pada saat pengambilan data). Jumlah sampel yang didapat sebanyak 60 siswa.

Pengumpulan data dilakukan dengan menggunakan wawancara dan observasi, serta menggunakan instrumen penelitian berupa lembar observasi yang digunakan untuk mengetahui tingkat preferensi terhadap makanan sekolah.

Analisis data dilakukan dengan menggunakan uji chi square untuk mengetahui hubungan antara faktor jenis kelamin anak, pendidikan ibu dan motivasi dari guru dengan preferensi makanan sekolah.

\section{HASIL}

\section{Preferensi makanan sekolah}

Dari hasil observasi yang dilakukan, makanan yang disajikan oleh sekolah termasuk dalam kategori makanan ringan. Di antara 46 jenis makanan sekolah yang disajikan tersebut, tidak semua termasuk dalam kategori makanan lokal seperti yang telah disarankan dalam PMTAS. Makanan lokal yang biasa dikonsumsi oleh masyarakat di daerah Purwokerto antara lain: tempe mendoan, getuk goreng, dan nopia.

Hasil penelitian tentang preferensi makanan sekolah pada anak TK UMP dapat dilihat pada Tabel 1. Dari hasil tersebut diketahui agar-agar dan sate telur puyuh merupakan jenis yang paling banyak disukai sampel dari semua jenis makanan yang disajikan oleh sekolah, masing-masing sejumlah 37 (61\%) dan 33 (55\%) sampel. Hal ini menunjukkan bahwa preferensi yang positif sampel terhadap makanan sekolah terlihat pada jenis makanan agar-agar dan sate telur puyuh.

Jenis makanan sus isi sayuran dan krekes goreng merupakan jenis makanan yang kurang disukai oleh sampel, dengan jumlah sampel masing-masing $25(41 \%)$ dan $28(46 \%)$ sampel. Dengan demikian, preferensi yang negatif sampel dapat ditunjukkan pada kedua jenis makanan tersebut.

\section{Hubungan antara jenis kelamin dengan preferensi makanan sekolah}

Berdasarkan jenis kelaminnya, tingkat preferensi makanan sekolah pada anak prasekolah berbeda-beda seperti disajikan pada Tabel 1. Dari tabel tersebut diketahui bahwa agar-agar merupakan makanan yang banyak disukai, baik oleh sampel laki-laki $(n=23)$ maupun sampel perempuan $(n=14)$. Preferensi sampel terhadap sate telur puyuh menempati urutan kedua setelah agar-agar, yaitu sampel laki-laki sebanyak 19 anak dan sampel perempuan sebanyak 14 anak. Sus isi sayuran dan krekes goreng cenderung kurang disukai oleh sampel dengan jumlah sampel masing-masing 35 dan 32 anak.

Dari berbagai jenis makanan yang disajikan, preferensi sampel terhadap makanan tersebut berbeda-beda. Terdapat perbedaan bermakna antara preferensi terhadap jenis makanan sate telur puyuh pada sampel laki-laki dan perempuan $(p<$ $0,05)$. Hal ini sesuai dengan hasil penelitian di Inggris yang mendapatkan hasil bahwa anak laki-laki cenderung menyukai daging dan telur (9). Dari observasi yang dilakukan, sate telur puyuh yang disajikan di sekolah merupakan makanan yang paling banyak dimakan habis oleh sampel, karena sate merupakan salah satu bentuk sajian telur puyuh yang menarik. Sampel perempuan kurang menyukai sate telur puyuh karena rasanya yang manis walau bentuknya menarik.

Preferensi sampel laki-laki dan perempuan terhadap jenis makanan agar-agar berbeda secara bermakna $(p<0,05)$. Sebanyak 23 sampel laki-laki dan 14 sampel perempuan menyukai jenis makanan ini. Agar-agar yang disajikan dalam suhu ruang dan menggunakan plastik ini disukai oleh anakanak karena rasanya yang manis dan frekuensi makan makanan yang tergolong sering di rumah. Hal ini sesuai dengan penelitian Worthington-Roberts dan Williams (10)

\section{TABEL 1. Tingkat preferensi makanan sekolah anak TK UMP berdasarkan jenis kelamin sampel}

\begin{tabular}{lccccc}
\hline Jenis makanan & Laki-laki & Perempuan & Total & Chi square & p \\
\hline Makanan yang disukai & & & & & \\
$\quad$ Agar-agar & 23 & 14 & 37 & 16,682 & $0,000^{*}$ \\
$\quad$ Sate telur puyuh & 19 & 14 & 33 & 7,636 & $0,006^{*}$ \\
Makanan yang kurang disukai & & & & & \\
$\quad$ Krekes goreng & 4 & 21 & 25 & 11,616 & $0,001^{*}$ \\
$\quad$ Sus isi sayuran & 7 & 21 & 28 & 6,000 & $0,014^{*}$ \\
\hline
\end{tabular}

Keterangan:

* Signifikan $(p<0,05)$ 
yang menyatakan bahwa anak-anak lebih menyukai makanan yang bersuhu ruangan, tidak panas maupun dingin.

Antara sampel laki-laki dan perempuan memiliki perbedaan bermakna dalam hal preferensi terhadap jenis makanan sus isi sayuran $(p<0,05)$. Sampel laki-laki sebanyak 4 anak menyukai jenis makanan ini, sedangkan sampel perempuan yang menyukai jenis makanan ini sebanyak 21 anak. Hal ini sesuai dengan hasil penelitian di Georgia yang menyatakan bahwa anak perempuan cenderung menyukai makanan yang mengandung sayuran dibanding anak laki-laki (15).

Preferensi sampel laki-laki dan perempuan terhadap makanan krekes goreng berbeda secara bermakna $(p<0,05)$. Sebanyak 18 orang sampel laki-laki dan 14 sampel anak perempuan menyatakan tidak suka makanan krekes goreng. Alasan yang dikemukakan pada umumnya karena tidak menyukai bagian dalam dari makanan tersebut yang berisi sayuran. Hal ini sesuai dengan teori yang menyatakan bahwa sayuran merupakan kelompok makanan yang kurang disukai anak-anak (11). Hasil ini sesuai dengan penelitian Hoerr et al. (14) yang menyatakan bahwa jenis kelamin berpengaruh terhadap perilaku makan. Perbedaan etnis juga berpengaruh terhadap konsumsi sayuran.

\section{Hubungan antara pendidikan ibu dengan preferensi makanan sekolah}

Hasil penelitian menunjukkan bahwa dari 60 orang ibu sampel, tingkat pendidikan tertinggi adalah sarjana sebanyak 22 orang dan yang terendah adalah tidak sekolah sebanyak 1 orang. Preferensi makanan sekolah berdasarkan tingkat pendidikan ibu sampel dapat dilihat pada Tabel 2.

Preferensi sampel terhadap makanan sekolah yang tergolong tinggi adalah agar-agar dan sate telur puyuh yang didominasi oleh sampel laki-laki dari ibu yang memiliki tingkat pendidikan sarjana, sedangkan pada jenis makanan sus isi sayuran dan krekes goreng didominasi oleh sampel perempuan dengan tingkat pendidikan ibu bukan sarjana.

Hasil uji chi square didapatkan nilai $p<0,05$ yang menunjukkan bahwa berdasarkan jenis kelamin, ada hubungan yang bermakna antara tingkat pendidikan ibu bukan sarjana dengan preferensi makanan agar-agar, sus isi sayuran, dan krekes goreng.

\section{Hubungan antara motivasi dari guru dengan preferensi makanan sekolah}

Dari observasi yang telah dilakukan, dapat diketahui bahwa semua sampel mendapatkan motivasi dari guru setiap acara makan bersama. Motivasi ini bertujuan agar anak mau menghabiskan makanan yang disajikan oleh sekolah tersebut. Namun demikian, preferensi sampel terhadap jenis makanan yang disajikan tetap berbeda. Sebanyak 37 sampel menyukai jenis makanan agar-agar, 33 sampel menyukai sate telur puyuh, 28 sampel menyukai krekes goreng, dan 25 sampel menyukai sus isi sayuran. Pada penelitian ini, tidak dilakukan uji statistik mengenai hubungan antara motivasi dari guru dengan preferensi makanan sekolah karena variabel motivasi dari guru diberikan sama kepada seluruh sampel (nilainya konstan).

\section{BAHASAN}

\section{Hubungan antara jenis kelamin anak terhadap makanan sekolah}

Jenis makanan dan minuman mempengaruhi persepsi rasa pada anak. Rasa tertentu seperti manis dan gurih akan mendorong anak untuk menyukai salah satu jenis makanan maupun minuman (16). Ukuran makanan juga berpengaruh terhadap preferensi anak terhadap makanan yang disukai. Menurut Patrick dan Nicklas (13), makin besar ukuran makanan, makin tinggi tingkat kesukaan anak terhadap makanan tersebut. Ada beberapa alasan anak tidak menyukai jenis makanan tertentu, seperti makanan yang lembek atau tidak dikenal. Kadang-kadang anak menolak makanan yang telah rusak, tetapi sedikit sering tidak menolak makanan yang bermerek. Frekuensi minum anak juga berpengaruh terhadap penurunan preferensi makanan anak (3).

TABEL 2. Preferensi makanan sekolah berdasarkan tingkat pendidikan ibu sampel

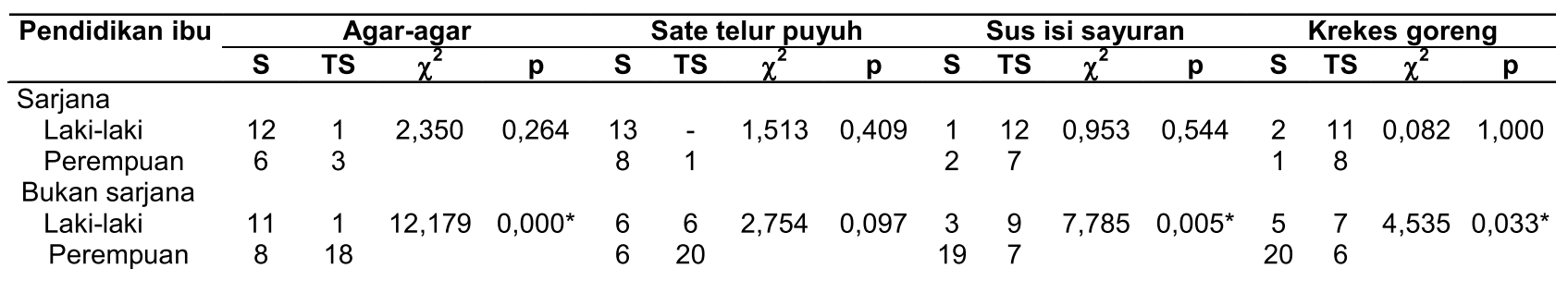

\footnotetext{
Keterangan:

$S$ (suka)

TS (tidak suka)

* Signifikan ( $p<0,05$; uji chi-square)
} 


\section{Hubungan antara pendidikan ibu terhadap makanan sekolah}

Orang tua mempunyai peranan penting dalam pembentukan kebiasaan makan dan preferensi kepada anak-anaknya. Mereka dapat mempengaruhi pemilihan makanan anak-anaknya dengan menyediakan makanan tertentu, bersikap sebagai model dan sikap pada situasi tertentu (17).

Program makanan sekolah juga dapat membantu meningkatkan status kesehatan anak-anak dan remaja. Ketersediaan makanan secara kompetitif dari mesin otomatis dan buatan rumah tangga memberi kesempatan tersedianya berbagai pilihan pada makanan sekolah. Sebanyak $25 \%$ anak dari sekolah menengah, $23 \%$ anak dari sekolah tingkat atas, dan $9 \%$ anak dari sekolah dasar menyukai makanan cepat saji (18). Makanan cepat saji umumnya diproduksi mesin otomatis dan sering tergolong makanan yang tinggi lemak dan nilai gizi yang rendah. Para peneliti di Amerika menemukan bahwa makanan alternatif yang tersedia pada mesin otomatis justru mempunyai efek negatif pada kualitas makanan pada anak sekolah (13). Penelitian ini sesuai dengan kondisi di Indonesia yang menunjukkan bahwa makanan jajanan anak mempunyai kualitas kesehatan yang rendah, sehingga perlu adanya program makanan sekolah seperti yang diterapkan di TK UMP.

Pendidikan orang tua yang tinggi (sarjana) lebih memiliki kesadaran akan pentingnya kesehatan dalam memilih makanan. Orang tua dengan pendidikan tinggi akan lebih berhati-hati dalam menyeleksi kandungan zat gizi dalam makanan. Pendapatan juga berpengaruh terhadap makanan yang adekuat. Anak yang berasal dari keluarga dengan tingkat pendapatan yang tinggi mempunyai preferensi makanan yang berbeda dengan anak yang berasal dari keluarga yang berpendapatan rendah (13). Anak-anak dan remaja dari keluarga dengan tingkat pendapatan yang tinggi biasanya lebih banyak mengkonsumsi makanan yang mengandung asam lemak tak jenuh ganda, protein, folat, kalsium, besi, selalu memperhatikan anjuran mengkonsumsi produk susu (19), vitamin, dan pola makan sesuai dengan asupan zat gizi yang dianjurkan (20); sementara anak-anak yang berasal dari keluarga bependapatan rendah kurang memperhatikan asupan zat gizi yang dianjurkan, asupan kalsium rendah (21), asupan mikronutrien rendah, persentase energi kebanyakan dari lemak, dan cenderung mengkonsumsi lemak susu utuh, serta proporsi energi dan nutrien lebih banyak dari makanan ringan (22).

Pendidikan formal yang tinggi merupakan syarat suatu pekerjaan tertentu, sehingga makin baik pekerjaan orang tua, pengetahuan dan gaya hidup juga makin meningkat. Ibu bekerja dengan kedudukan yang tinggi mempunyai kebiasaan pola konsumsi makanan yang berbeda dengan ibu bekerja dengan kedudukan yang lebih rendah. Oleh karena itu, pola konsumsi makanan secara tidak langsung dipengaruhi oleh tingkat pendidikan. Pengetahuan gizi yang baik juga berpengaruh terhadap kebiasaan pola konsumsi makanan. Pola preferensi dan asupan makanan anak dibentuk melalui pengalaman awal dengan makanan dan makan, serta praktik orang tua dalam memberikan makan pada anak, hal ini merupakan gambaran utama pengalaman awal anak untuk makan (12).

\section{Hubungan antara motivasi dari guru terhadap preferensi makanan sekolah}

Pada penelitian ini, sebanyak 37 sampel menyukai jenis makanan agar-agar, 33 sampel menyukai sate telur puyuh, 28 sampel menyukai krekes goreng, dan 25 sampel menyukai sus isi sayuran. Motivasi yang diberikan oleh guru saat acara makan bersama dapat mendorong anak-anak untuk mau menerima makanan yang disajikan. Teacher modelling merupakan suatu metode yang paling efektif untuk mendorong penerimaan makanan oleh anak-anak usia prasekolah. Guru yang aktif akan lebih efektif dalam mendorong penerimaan makanan pada anak-anak prasekolah dibandingkan dengan guru yang pasif (diam) (23).

Makanan yang disukai sampel akan dimakan habis oleh sampel. Hal ini dapat disebabkan sampel memang menyukai jenis makanan tersebut dan sudah sering mengkonsumsi makanan tersebut di luar sekolah (di rumah), sehingga anak mau menghabiskan makanan tersebut tanpa adanya motivasi dari guru. Sebaliknya, makanan yang tidak disukai sampel tidak dimakan habis, meskipun guru telah memberikan motivasi. Hal ini dapat disebabkan oleh faktor-faktor lain yang dapat mempengaruhi preferensi makanan sekolah antara lain: sosial ekonomi, budaya, kondisi psikologis, dan lingkungan serta faktor dari makanan itu sendiri $(12,24,25)$.

Preferensi ibu juga dapat mempengaruhi preferensi makanan pada anaknya (26). Selain pengaruh dari orang tua, saudara kandung di rumah, kelompok bermain, dan pujian atau respon negatif (larangan) untuk mengkonsumsi makanan tertentu juga mempengaruhi preferensi makanan pada anak $(4,14)$. Untuk beberapa jenis makanan, media dan iklan berdampak terhadap penilaian anak dalam menyeleksi makanan tertentu. Penelitian di Amerika dan di Australia menunjukkan bahwa iklan berpengaruh terhadap anak untuk mengkonsumsi makanan tertentu $(27,28)$.

Pemberian hadiah untuk mengkonsumsi makanan tertentu justru dapat meningkatkan ketidaksukaan terhadap makanan tersebut. Pujian secara verbal dalam konteks sosial juga dapat meningkatkan kesukaan anak terhadap makanan. Tidak hanya sering melihat, tetapi kesempatan untuk merasakan makanan dapat meningkatkan penerimaan makanan. Dalam keluarga, karakteristik fungsional keluarga dapat meningkatkan perilaku tertentu, baik positif maupun negatif. Konflik dalam keluarga, pengawasan, keterpaduan, dan parameter lain berpengaruh terhadap asupan makanan dari anggota keluarga termasuk anak (5). 
Kepercayaan dan sikap orang tua terhadap makanan juga berpengaruh terhadap preferensi anak. Orang tua percaya bahwa makanan menyehatkan dan pengalaman makan mereka sebelumnya juga berhubungan dengan asupan makan anak. Anak belajar tentang makanan tidak hanya lewat pengalaman pribadi, tetapi juga melihat pengalaman orang lain. Makan bersama dalam satu meja menjadi efek yang penting pada pola konsumsi makanan anak, terutama dalam hal mengkonsumsi makanan dan zat gizi yang lebih menyehatkan. Gaya makan orang tua berpengaruh terhadap preferensi makanan anak. Orang tua akan membatasi konsumsi makanan yang tidak baik bagi anak dan menyarankan asupan makanan yang lebih baik (13).

Informasi kesehatan tidak selalu berakibat positif terhadap preferensi anak. Anak percaya bahwa makanan yang sehat dan bercita rasa tinggi adalah karakteristik yang eksklusif, sehingga anak justru tidak akan menyukainya (29).

\section{RUJUKAN}

1. Santoso S, Ranti AL. Kesehatan dan Gizi. Jakarta: EGC; 2004.

2. Paath EF, Rumdasih Y, Heryati. Gizi dalam Kesehatan Reproduksi. Jakarta: EGC; 2005.

3. Wright CM, Parkinson KN, Shipton D, Drewett RF. How Do Toddler Eating Problems Relate to Their Eating Behavior, Food Preferences, and Growth? Pediatr 2007;120(4):1069-75.

4. Carruth BR, Skinner JD. Revisiting the Picky Eater Phenomenon: Neophobic Behaviors of Young Children. J Am Coll Nutr 2000;19(6):771-80.

5. Carruth BR, Skinner J, Houck K, Moran J, Coletta F, Ott D. The Phenomenon of "Picky Eater": ABehavioral Marker in Eating Patterns of Toddlers. J Am Coll Nutr 1998;17(2):180-6.

6. Drewnowski A, Kurth CL, Rahaim JE. Taste Preferences in Human Obesity: Environmental and Familiar Factors. Am J Clin Nutr 1991;54:635-41.

7. Lucas B. Krause's Food, Nutrition, \& Diet Theraphy. USA: WB Saunders; 2000.

8. Drewnowski A, Hann C. Food Preferences and Reported Frequencies of Food Consumption as Predictors of Current Diet in Young Women. Am J Clin Nutr 1999;70(1):28-36.

9. Cooke LJ, Wardle J. Age and Gender Differences in Children's Food Preferences. Br J Nutr 2005;93(5):741-6.

10. Worthington-Roberts BS, Williams SR. Nutrition Throughout The Life Cycle. USA: The McGraw-Hill Companies; 2000.

11. Kretchmer N, Zimmermann M. Developmental Nutrition. USA: Allyn and Bacon; 1997.

12. Birch LL, Fisher JO. Development of Eating Behaviors among Children and Adolescents. Pediatr 1998;101:539-49.

\section{KESIMPULAN DAN SARAN}

Ada hubungan antara jenis kelamin anak prasekolah TK UMP dengan preferensi makanan sekolah, begitu pula dengan hubungan antara pendidikan ibu dengan preferensi makanan sekolah. Motivasi yang diberikan oleh guru saat acara makan bersama dapat mendorong anak-anak untuk mau menerima makanan yang disajikan.

Saran yang dapat diberikan dari penelitian ini adalah pentingnya meningkatkan konsumsi makanan bergizi dengan diversifikasi bentuk dan jenis makanan sesuai preferensi yang disukai oleh anak laki-laki maupun perempuan. Orang tua dan guru perlu menggunakan data tentang preferensi makanan anak sebagai dasar dalam memotivasi anak untuk mengkonsumsi makanan. Penelitian lebih lanjut dengan menyertakan berbagai variabel yang secara teoretis ikut berperan dalam preferensi makanan anak seperti bentuk, tekstur, dan suhu makanan perlu dilakukan.

13. Patrick H, Nicklas TA. A Review of Family and Social Determinants of Children's Eating Patterns and Diet Quality. J Am Coll Nutr 2005;24(2):83-92.

14. Hoerr SL, Bokram R, Lugo B, Bivins T, Keast TR. Risk for Disordered Eating Relates to both Gender and Ethnicity for College Students. J Am Coll Nutr 2002:21(4);307-14.

15. Reynolds KD, Baranowski T, Bishop DB, Farris RP, Binkley HD, Nicklas TA, et al. Patterns in Child and Adolescent Consumption of Fruit and Vegetables: Effects of Gender and Ethnicity across Four Sites. J Am Coll Nutr 1999;18(3):248-54.

16. Robinson TR, Borzekowski DLG, Matheson DM, Kraemer HC. Effects of Fast Food Branding on Young Children's Taste Preferences. Arch Pediatr Adolesc Med 2007;161(8):792-7.

17. Klesges RC, Stein RJ, Eck LH, Isbell TR, Klesges LM. Parental Influence on Food Selection in Young Children and Its Relationships to Childhood Obesity. Am J Clin Nutr 1991;53:859-64.

18. Story M, Evans M, Fabsitz RR, Clay TE, Holy Rock B, Broussard B. The Epidemic of Obesity in American Indian Communities and The Need for Childhood ObesityPrevention Programs. Am J Clin Nutr 1999;69(4 Suppl):747S -54S.

19. Xie B, Gilliland FD, Li YF, Rockett HR. Effects of Ethnicity, Family Income, and Education on Dietary Intake among Adolescents. Prev Med 2003;36:30-40.

20. Lee MM, Huang S. Immigrant Women's Health: Nutritional Assessment and Dietary Intervention. West J Med 2001;175:133-7.

21. Wyatt CJ, Triana Tejas MA. Nutrient Intake and Growth of Preschool Children from Different Socioeconomic Regions in The City of Oaxaca, Mexico. Ann Nutr Metab 2000;44:14-20. 
22. Ruxton $\mathrm{CH}$, Kirk TR, Belton NR, Holmes MA. Relationships Between Social Class, Nutrient Intake and Dietary Patterns in Edinburgh Schoolchildren. Int J Food Sci Nutr 1996;47:341-9.

23. Hendy HM, Raudenbush B. Effectiveness of Teacher Modeling to Encourage Food Acceptance in Preschool Children. Appetite 2000;34(1);61-76.

24. Lindmark U, Stegmayr B, Nilsson B, Lindah B, Johansson I. Food Selection Associated with Sense of Coherence in Adults. J Nutr 2005;4(9):1-7.

25. Hakkarainen R, Partonen T, Haukka J, Virtamo J, Albanes $\mathrm{D}$, and Lonnqvist J. Food and Nutrient Intake in Relation to Mental Wellbeing. J Nutr 2004;3(14):1-5.
26. Skinner JD, Carruth BR, Wendy B, Ziegler PJ. Children's Food Preferences: A Longitudinal Analysis. J Am Diet Assoc 2002;102(11):1638-47.

27. Powell LM, Szczypka G, Chaloupka FJ. Exposure to Food Advertising on Television Among US Children. Arch Pediatr Adolesc Med 2007;161:553-60.

28. Neville L, Thomas M, Bauman A. Food Advertising on Australian Television: The Extent of children's Exposure. Health Promotion International 2005;20(2):10512.

29. Wardle J, Huon G. An Experimental Investigation of The Influence of Health Information on Children's Taste Preferences. Health Educ Res 2000;15(1):30-44. 